Cover: Photograph showing Lake Spokane shoreline west of Tumtum, Washington. Photograph by Andrew Gendaszek, U.S. Geological Survey, August 21, 2014. 


\section{Preliminary Characterization of Nitrogen and Phosphorus in Groundwater Discharging to Lake Spokane, Northeastern Washington, Using Stable Nitrogen Isotopes}

By Andrew S. Gendaszek, Steven E. Cox, and Andrew R. Spanjer

Prepared in cooperation with the Washington State Department of Ecology

Open-File Report 2016-1029

U.S. Department of the Interior

U.S. Geological Survey 


\section{U.S. Department of the Interior \\ SALLY JEWELL, Secretary}

\section{U.S. Geological Survey \\ Suzette M. Kimball, Director}

U.S. Geological Survey, Reston, Virginia: 2016

For more information on the USGS—-the Federal source for science about the Earth,

its natural and living resources, natural hazards, and the environment-visit

http://www.usgs.gov or call 1-888-ASK-USGS (1-888-275-8747)

For an overview of USGS information products, including maps, imagery, and publications, visit http://www.usgs.gov/pubprod

To order this and other USGS information products, visit http://store.usgs.gov

Any use of trade, firm, or product names is for descriptive purposes only and does not imply endorsement by the U.S. Government.

Although this information product, for the most part, is in the public domain, it also may contain copyrighted materials as noted in the text. Permission to reproduce copyrighted items must be secured from the copyright owner.

Suggested citation:

Gendaszek, A.S., Cox, S.E., and Spanjer, A.R., 2016, Preliminary characterization of nitrogen and phosphorus in groundwater discharging to Lake Spokane, northeastern Washington, using stable nitrogen isotopes: U.S. Geological Survey Open-File Report 2016-1029, 22 p., http://dx.doi.org/10.3133/ofr20161029.

ISSN 2331-1258 (online) 


\section{Contents}

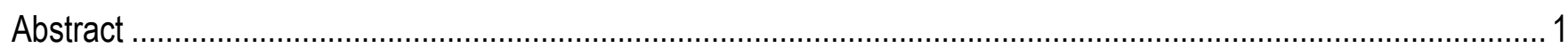

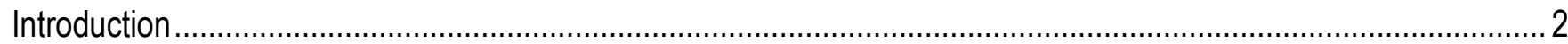

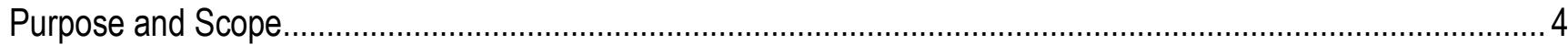

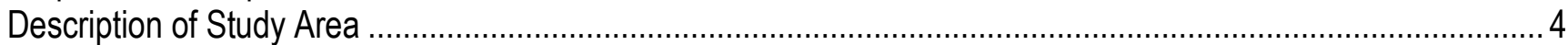

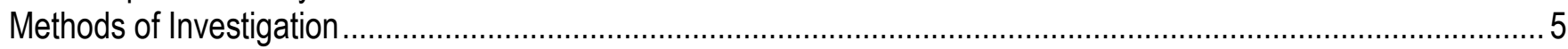

Aquatic Vegetation Sampling, N-lsotope Analysis, and Quality Control...........................................................

Water-Quality Data Collection, Analysis, and Quality Control ........................................................................ 8

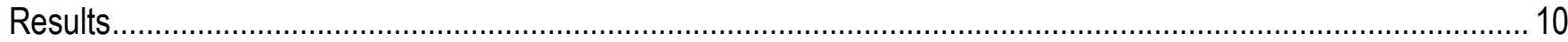

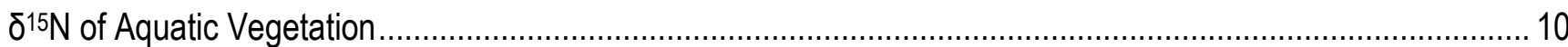

Nitrogen and Phosphorus Concentrations in Shallow Groundwater.......................................................... 12

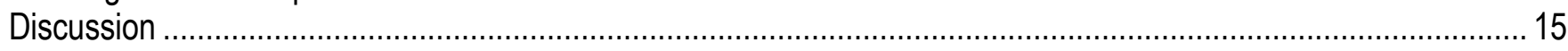

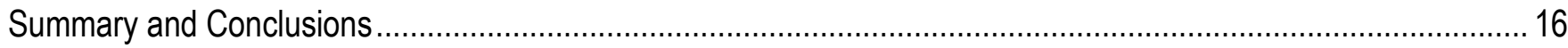

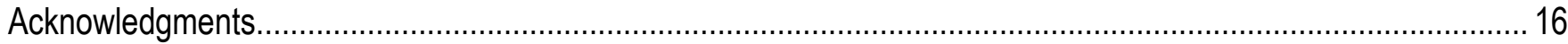

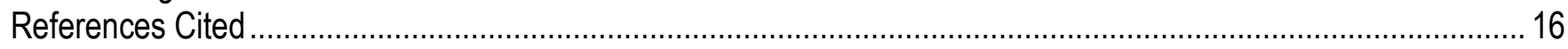

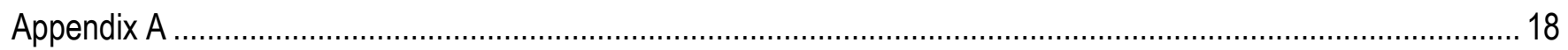

Figures

Figure 1. Map showing location of Lake Spokane study area, Stevens and Spokane Counties,

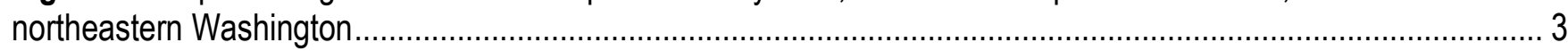

Figure 2. Maps showing locations of Richardson's pondweed sample collection sites in eastern Lake Spokane (A) and central Lake Spokane (B), northeastern Washington.................................................... 7

Figure 3. Map showing location of shallow piezometers installed at 30 locations near the shoreline of

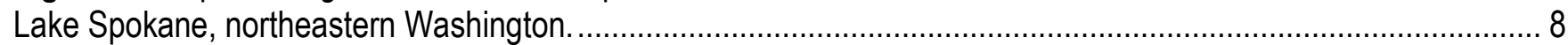

Figure 4. Boxplot showing $\delta^{15} \mathrm{~N}$ in Richardson's pondweed for sampled land uses in Lake Spokane, northeastern Washington

Figure 5. Boxplot showing nitrate plus nitrite concentrations in groundwater for sampled land uses near the shoreline of Lake Spokane, northeastern Washington

Figure 6. Boxplot showing orthophosphate concentrations in groundwater for sampled land uses near the shoreline of Lake Spokane, northeastern Washington

\section{Tables}

Table 1. Summary statistics of $\delta^{15} \mathrm{~N}$ values in Richardson's pondweed for sampled land uses in Lake Spokane, northeastern Washington.

Table 2. Nitrogen and orthophosphate concentrations in groundwater for sampled land uses near the shoreline of Lake Spokane, northeastern Washington .. 


\section{Conversion Factors}

Inch/Pound to International System of Units

\begin{tabular}{lcll}
\hline & Multiply & By & To obtain \\
\hline inch (in) & Length & \\
foot (ft) & 2.54 & centimeter $(\mathrm{cm})$ & \\
mile (mi) & 0.3048 & meter $(\mathrm{m})$ & \\
\hline \multicolumn{5}{c}{ Area } \\
\hline acre & 1.609 & kilometer $(\mathrm{km})$ & \\
\hline \multicolumn{5}{c}{ Volume } \\
\hline acre-foot & 4,047 & square meter $\left(\mathrm{m}^{2}\right)$ \\
\hline
\end{tabular}

International System of Units to Inch/Pound

\begin{tabular}{ccc}
\hline Multiply & By & To obtain \\
\hline & Volume & \\
\hline $\operatorname{liter}(\mathrm{L})$ & 0.2641 & gallon (gal) \\
\hline
\end{tabular}

\section{Datums}

Vertical coordinate information is referenced to the North American Vertical Datum of 1988 (NAVD 88).

Horizontal coordinate information is referenced to the North American Datum of 1983 (NAD 83).

Elevation, as used in this report, refers to distance above the vertical datum. 


\title{
Preliminary Characterization of Nitrogen and Phosphorus in Groundwater Discharging to Lake Spokane, Northeastern Washington, Using Stable Nitrogen Isotopes
}

\author{
By Andrew S. Gendaszek, Stephen E. Cox, and Andrew R. Spanjer
}

\begin{abstract}
Lake Spokane, locally referred to as Long Lake, is a 24-mile-long section of the Spokane River impounded by Long Lake Dam that has, in recent decades, experienced water-quality problems associated with eutrophication. Consumption of oxygen by the decomposition of aquatic plants that have proliferated because of high nutrient concentrations has led to seasonally low dissolved oxygen concentrations in the lake. Of nitrogen and phosphorus, the two primary nutrients necessary for aquatic vegetation growth, phosphorus was previously identified as the limiting nutrient that regulates the growth of aquatic plants and, thus, dissolved oxygen concentrations in Lake Spokane. Phosphorus is delivered to Lake Spokane from municipal and industrial point-source inputs to the Spokane River upstream of Lake Spokane, but is also conveyed by groundwater and surface water from nonpointsources including septic tanks, agricultural fields, and wildlife. In response, the Washington State Department of Ecology listed Lake Spokane on the 303(d) list of impaired water bodies for low dissolved oxygen concentrations and developed a Total Maximum Daily Load for phosphorus in 1992, which was revised in 2010 because of continuing algal blooms and water-quality concerns.

This report evaluates the concentrations of phosphorus and nitrogen in shallow groundwater discharging to Lake Spokane to determine if a difference exists between nutrient concentrations in groundwater discharging to the lake downgradient of residential development with on-site septic systems and downgradient of undeveloped land without on-site septic systems. Elevated nitrogen isotope values $\left(\delta^{15} \mathrm{~N}\right)$ within the roots of aquatic vegetation were used as an indicator of septic-system derived nitrogen. $\delta^{15} \mathrm{~N}$ values were measured in August and September 2014 downgradient of residential development near the lakeshore, of residential development on 300-ft-high terraces above the lake, and of undeveloped land in the eastern (upper) and central (lower) parts of Lake Spokane. Significantly lower $\delta^{15} \mathrm{~N}$ values were measured within aquatic vegetation downgradient of undeveloped land in eastern Lake Spokane relative to both near-shore and terrace residential development land uses. Conversely, significantly higher $\delta^{15} \mathrm{~N}$ values were measured downgradient of undeveloped land in central Lake Spokane relative to the two developed land uses. These results guided the location of subsequent groundwater sampling in March and April 2015 from 30 shallow piezometers driven into the near-shore area of Lake Spokane. Nitrate plus nitrite concentrations in groundwater discharging to Lake Spokane downgradient of undeveloped areas were significantly lower than those measured downgradient of both near-shore and terrace residential development. Orthophosphate concentrations in groundwater were not significantly different with respect to upgradient land use.
\end{abstract}




\section{Introduction}

Lake Spokane, locally referred to as Long Lake, is formed by the impoundment of the Spokane River by Long Lake Dam about 10 mi northwest of Spokane, Washington, and forms the boundary between Stevens and Spokane Counties (fig. 1). Seasonal water-quality impairments of Lake Spokane related to eutrophication including algal blooms and low dissolved-oxygen concentrations have occurred for several decades (for example, Wagstaff and Soltero, 1982; Soltero and others, 1992). High nutrient loads into the lake have contributed to eutrophication resulting in high productivity of aquatic plants and algae, the decomposition of which by oxygen-consuming bacteria contributes to low dissolved oxygen concentrations. The failure of Lake Spokane to meet Washington State water-quality standards for dissolved oxygen resulted in its inclusion within Washington State Department of Ecology's (Ecology) list of impaired waterbodies under Section 303(d) of the Clean Water Act in 1992 and in the development of a Total Maximum Daily Load (TMDL) for phosphorus in 1992, which was revised in 2010 owing to continuing algal blooms and water-quality concerns (Moore and Ross, 2010). Patmont and others (1987) evaluated the response of periphyton communities to nitrogen and phosphorus loading and concluded that periphyton growth in Lake Spokane was limited by phosphorus. Potential sources of phosphorus and nitrogen to Lake Spokane include point sources such as municipal wastewater-treatment plants and industrial discharges and non-point sources within the Spokane River watershed upstream of Lake Spokane. Non-point sources of phosphorus include eroded soils, plant matter, wildlife, human waste, and fertilizers. Whereas the upstream phosphorus and nitrogen load to Lake Spokane from point sources is relatively well documented through National Pollution Discharge Elimination System (NPDES) permits (Cusimano, 2004), phosphorus and nitrogen loading from non-point sources such as onsite septic systems (OSS) is not well known. The present study partly addressed this uncertainty by first determining locations along the shoreline where the nitrogen isotope ratio $\left(\delta^{15} \mathrm{~N}\right)$ value of rooted aquatic vegetation suggests that discharging groundwater contains the effluent of OSS wastewater and then determining if there is a statistical difference between nutrient concentrations of groundwater discharging downgradient of developed land and undeveloped land without OSS. Because rates of groundwater exchange into Lake Spokane were not measured, fluxes of phosphorus and nitrogen into Lake Spokane were not estimated. 


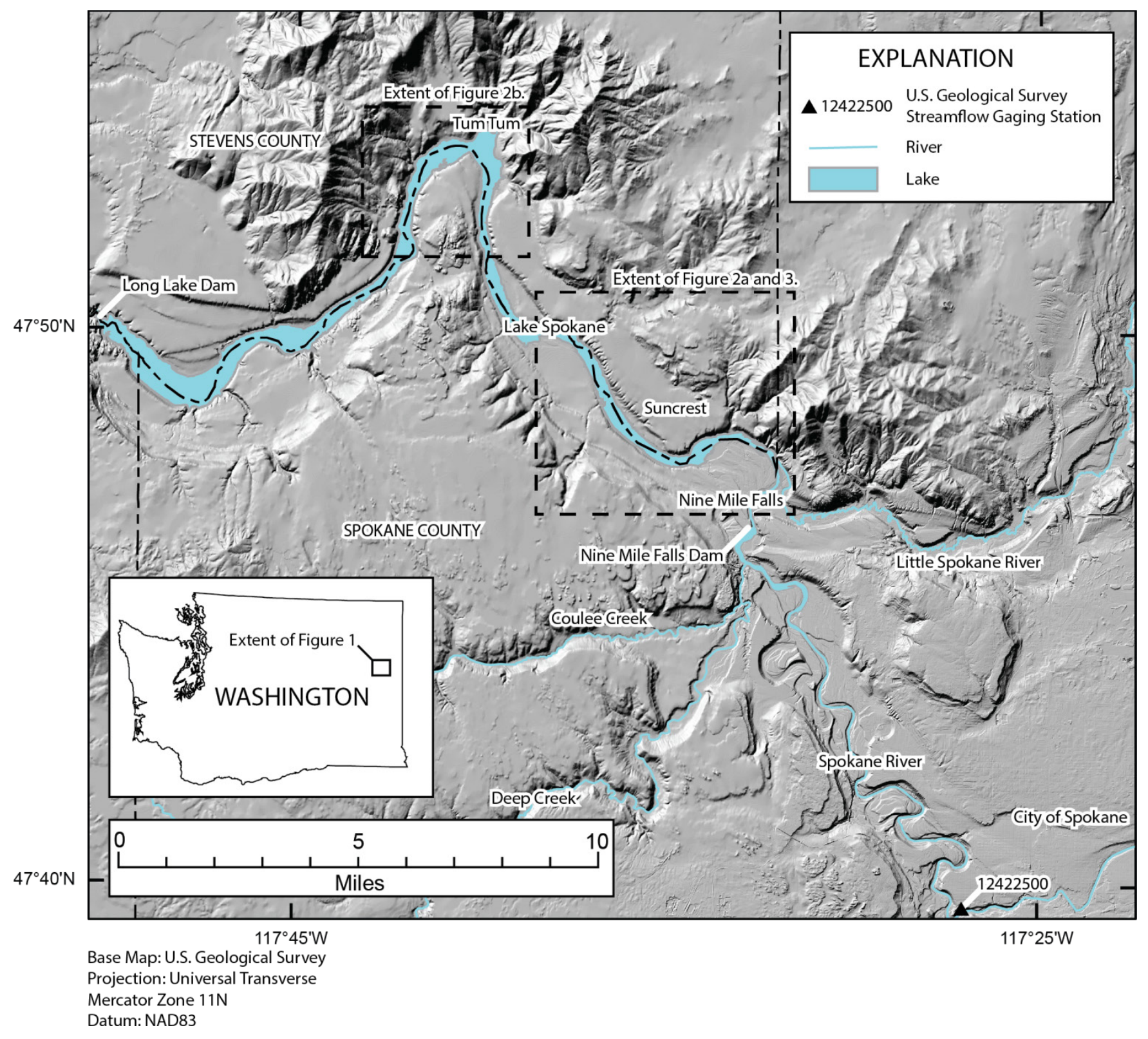

Figure 1. Map showing location of Lake Spokane study area, Stevens and Spokane Counties, northeastern Washington. 


\section{Purpose and Scope}

The purpose of this report is to evaluate the difference in the nutrient concentration of groundwater discharging into Lake Spokane downgradient of developed areas containing OSS and undeveloped areas that do not contain OSS. Although nitrogen moves readily through shallow aquifers, these data will help determine if aquifer materials are saturated with respect to phosphorus, which readily absorbs to sediments in such a way that additional phosphorus is transmitted through the aquifer to Lake Spokane. The report includes a discussion of (1) $\delta^{15} \mathrm{~N}$ of rooted aquatic plants to determine locations where groundwater discharging into Lake Spokane contains components of OSS effluent and (2) an evaluation of nitrogen and phosphorus concentrations of groundwater discharging into Lake Spokane downgradient of developed areas containing OSS and undeveloped areas that do not contain OSS. Water-quality samples were collected in spring 2015, and $\delta^{15} \mathrm{~N}$ samples were collected in summer 2014.

\section{Description of Study Area}

The impoundment of the Spokane River at Long Lake Dam forms a 24-mi-long, 5,000-acre reservoir called Lake Spokane that has 243,000 acre-ft of water and $54 \mathrm{mi}$ of shoreline (fig. 1). Upstream of Nine Mile Dam, which is immediately upstream of Lake Spokane, the Spokane River drains 5,220 $\mathrm{mi}^{2}$ of northeastern Washington and northern Idaho, including the city of Spokane. Several unregulated tributaries flow into Lake Spokane, the largest of which is the Little Spokane River, which enters Lake Spokane 1.75 mi downstream of Nine Mile Dam.

The predominant land uses surrounding Lake Spokane are undeveloped Ponderosa Pine forest, agriculture, and rural residential development within three unincorporated communities including Nine Mile Falls, Suncrest, and Tum Tum, where the 2010 population was about 8,000 (U.S. Census Bureau, 2015). Residential development near Lake Spokane occurs along the shoreline and on 300-ft-high terraces. Sewage from houses and businesses is treated by OSS throughout the area surrounding Lake Spokane. Shallow groundwater primarily flows through unconsolidated Pleistocene outburst flood sediments with dominant groundwater-flow directions perpendicular to the Lake Spokane shoreline (Soltero and others, 1992).

Discharge of the Spokane River is regulated at Long Lake Dam, which was completed in 1915, for hydroelectric power generation by Avista Utilities. Mean monthly discharge measured from water years 1892 to 2014 at the Spokane River at Spokane, Washington (U.S. Geological Survey [USGS] streamflow-gaging station 12422500) ranges from a high of 17,700 $\mathrm{ft}^{3} / \mathrm{s}$ in May during snowmelt to a low of $1,690 \mathrm{ft}^{3} / \mathrm{s}$ in August during summer baseflow. The pool elevation of Lake Spokane is held at approximately $1,535 \mathrm{ft}$ above sea level for most of the year except for short periods of $10-\mathrm{ft}$ drawdown during the winter intended to manage pervasive aquatic plants by freezing them in shallow areas of the lake. Lake Spokane is shallowest at the outlet of Nine Mile Dam and becomes increasingly deeper towards Long Lake Dam, where maximum water depths approach $180 \mathrm{ft}$. 


\section{Methods of Investigation}

Field data were collected in two phases during summer 2014 and spring 2015 to first identify where groundwater containing septic-system effluent discharges into Lake Spokane and then to measure the concentration of nutrients in near-shore groundwater discharging to Lake Spokane downgradient of developed and undeveloped land. During the first phase in August and September 2014, Richardson's pondweed (Potamogeton richardsoni) was collected from 84 locations in Lake Spokane and analyzed for nitrogen isotope concentrations at the University of California-Davis, Stable Isotope Facility. During the second phase in March and April 2015, shallow piezometers were installed at 30 locations in the nearshore of Lake Spokane. Groundwater was sampled from these piezometers and analyzed for nutrient concentrations at the USGS National Water Quality Laboratory in Lakewood, Colorado.

\section{Aquatic Vegetation Sampling, N-Isotope Analysis, and Quality Control}

Elevated values of $\delta^{15} \mathrm{~N}$ in plant tissues can be indicative of nitrogen from anthropogenic sources like OSS (Cole and others, 2005). The relative abundance of the stable nitrogen isotopes ${ }^{15} \mathrm{~N}$ and ${ }^{14} \mathrm{~N}$ within aquatic plants that do not fix nitrogen from the atmosphere is primarily determined by the isotopic composition of water that they uptake through their roots, leaves, and shoots. The ratio of ${ }^{15} \mathrm{~N}$ to ${ }^{14} \mathrm{~N}$ is commonly expressed as $\delta^{15} \mathrm{~N}(\%)=\left[\left(\mathrm{R}_{\text {sample }}-\mathrm{R}_{\text {reference }}\right) / \mathrm{R}_{\text {reference }}\right] \times 1,000$, where $\mathrm{R}$ is ${ }^{15} \mathrm{~N} /{ }^{14} \mathrm{~N}$ and reference is atmospheric $\mathrm{N}_{2}$. Reporting units are parts per thousand (\%o). Fractionation of the common stable nitrogen isotope, ${ }^{14} \mathrm{~N}$, and a rare stable nitrogen isotope, ${ }^{15} \mathrm{~N}$, occurs in the environment through biogeochemical processes including nitrification, denitrification, and $\mathrm{N}_{2}$ fixation. Nitrate within the solid waste of humans, who occupy a higher trophic level, becomes enriched in ${ }^{15} \mathrm{~N}$ (that is, isotopically heavier) due to metabolic processes, which may be further enriched within septic systems due to denitrification resulting in wastewater with $\delta^{15} \mathrm{~N}$ values between +10 and $+30 \%$ (Finlay and Kendall, 2007). As a result, the $\delta^{15} \mathrm{~N}$ value of nitrate within septic wastewater becomes distinguishable from groundwater with nitrate that is derived from atmospheric deposition, which has an isotopically lighter value of between -8 and $+3 \%$ (Peterson and Fry, 1987; Kendall, 1998; Kendall and others, 2007). 
Richardson's pondweed was selected for $\delta^{15} \mathrm{~N}$ analysis because it is rooted in the lakebed and occurs prolifically throughout Lake Spokane. Limiting sampling of aquatic vegetation for $\delta^{15} \mathrm{~N}$ analysis to a single species prevented complications in the interpretations of $\delta^{15} \mathrm{~N}$ values due to differential nitrogen isotope fractionation between plant species. Whole plants of Richardson's pondweed were collected by hand in shallow (about 3- to 8-ft deep) water near the shoreline of Lake Spokane. In August and September 2014, a total of 84 sites were sampled (fig. 2) and site locations were distributed downgradient of near-shore residential development (NSRD; $n=21)$, terrace residential development (TRD; $n=31$ ), undeveloped land in eastern Lake Spokane (EUND; $n=12$ ), and undeveloped land in central Lake Spokane (CUND; $n=20$ ). Whole plant samples were refrigerated and transported to the USGS Washington Water Science Center Laboratory in Tacoma, Washington, where roots were separated, cleaned with deionized water, weighed with an analytical balance to $\pm 0.0001 \mathrm{~g}$, and placed in a drying oven at $60{ }^{\circ} \mathrm{C}$ for a minimum of $24 \mathrm{~h}$. $\delta^{15} \mathrm{~N}$ analyses were limited to roots to increase the likelihood that the nitrogen sampled was derived from the uptake of pore water beneath the lakebed. Samples were considered dry when decreases in weight were less than 1 percent per hour measured using an analytical balance. Dried material was ground using a Teflon ${ }^{\circledR}$ tissue grinder and glass mortar and pestle. Five to $6 \mathrm{~g}$ of dried Richardson's pondweed roots from each site were packaged in aluminum foil for shipment to University of California-Davis, Stable Isotope Facility for nitrogen isotope analysis by Elemental Analysis-Isotope Ratio Mass Spectrometry. Nine quality-control field replicates were analyzed to assess total variability in the data due to collection, processing, and laboratory analysis. Relative percent differences in the pairs of $\delta^{15} \mathrm{~N}$ values between replicates and their accompanying sample ranged from 0 to 2.3 percent. Standard reference materials including glutamic acid and ground peach leaves with known $\delta^{15} \mathrm{~N}$ values were analyzed in the same batches as the environmental samples.

The non-parametric Wilcoxon rank-sum test was used to assess whether relative abundances of $\delta^{15} \mathrm{~N}$ measured in the roots of Richardson's pondweed downgradient of each of the land uses were significantly different (Helsel and Hirsch, 2002). The null hypothesis that no difference between the populations of $\delta^{15} \mathrm{~N}$ collected downgradient of different land uses was rejected if the corresponding Wilcoxon rank-sum test yielded a $p$-value of $\leq 0.05$. 


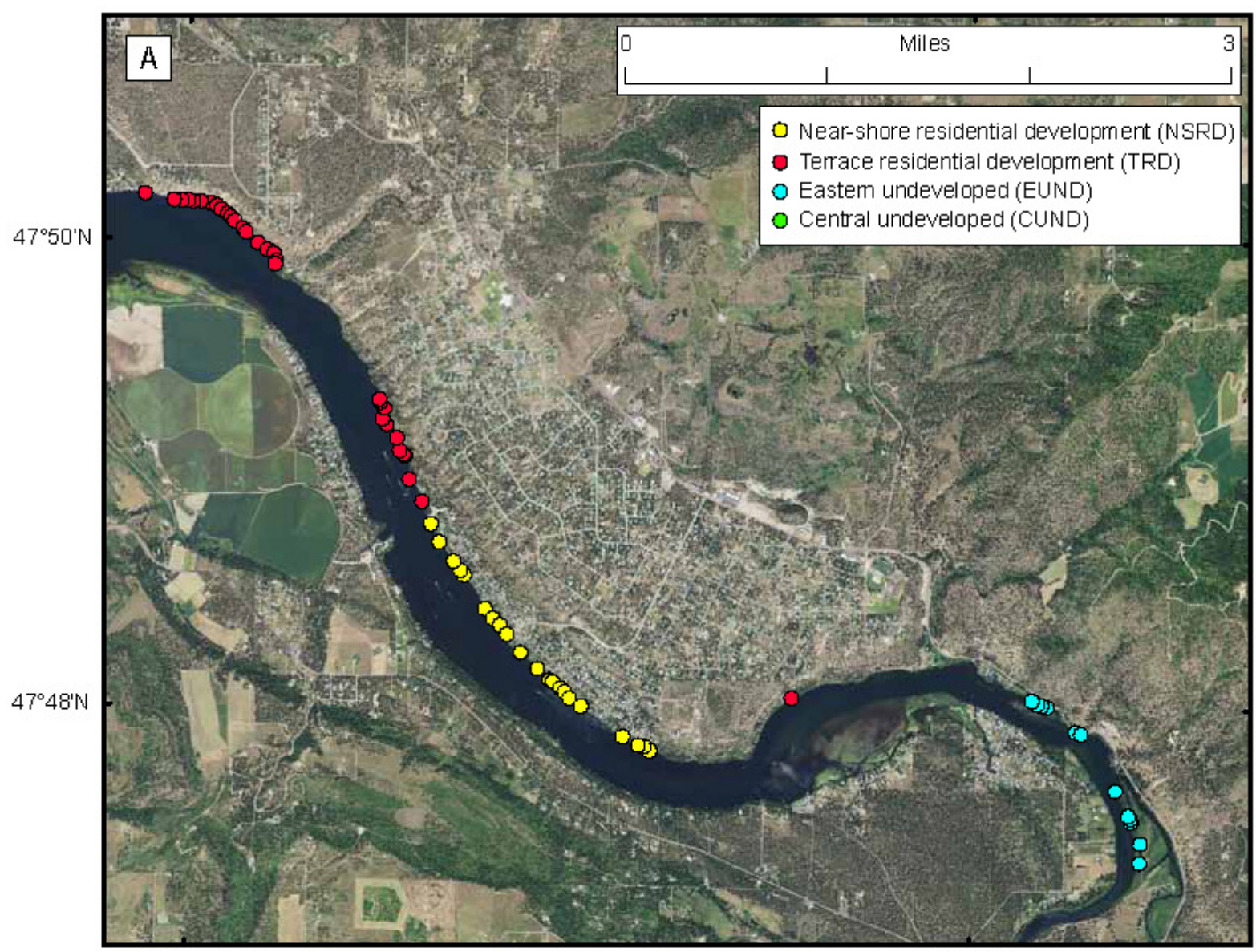

$117^{\circ} 38 \mathrm{~W}$

$117^{\circ} 33^{\prime W}$

Base Map: USDANAIP (2011) Projection: Universal Transverse Mercator Zone $11 \mathrm{~N}$

Datum: NADB3

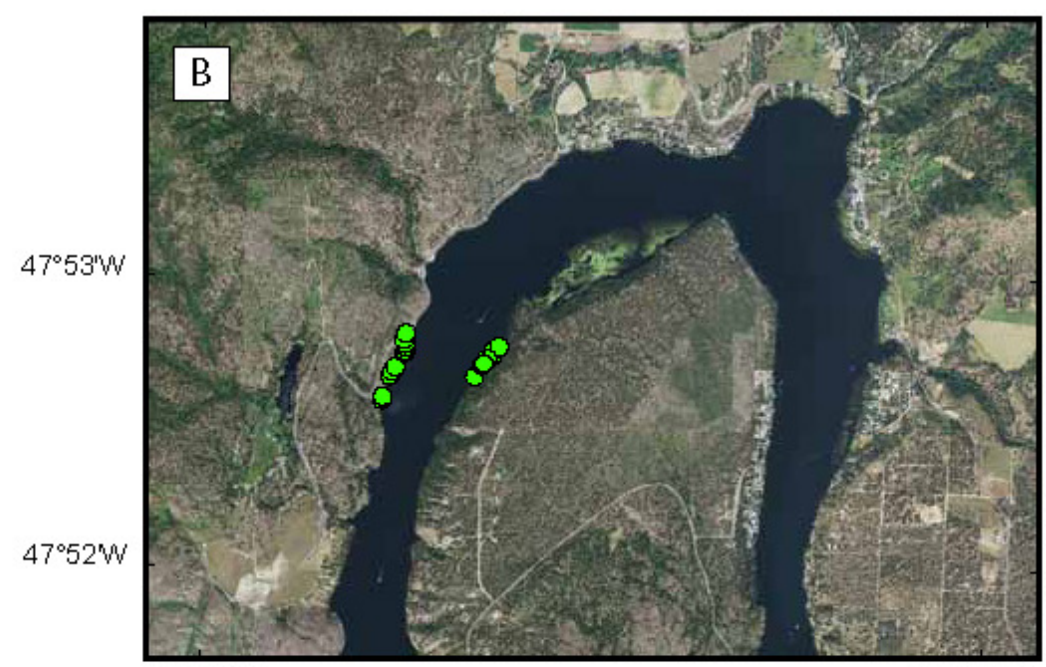

$117^{\circ} 43^{\mathrm{W}}$

$117^{\circ} 39^{\prime} \mathrm{W}$

Base Map: USDANAIP (2011)

Projection: Universal Transverse

Mercator Zone $11 \mathrm{~N}$

Datum: NAD 83

Figure 2. Maps showing locations of Richardson's pondweed sample collection sites in eastern Lake Spokane (A) and central Lake Spokane (B), northeastern Washington. 


\section{Water-Quality Data Collection, Analysis, and Quality Control}

Near-surface groundwater was collected from shallow piezometers installed at 30 locations in Lake Spokane in the lakebed within $20 \mathrm{ft}$ of the shoreline (fig. 3). Nineteen piezometers were installed and sampled during March 24-26, 2015, and 11 piezometers were installed and sampled between April 29 and 30, 2015. Each piezometer was installed using a hand-held post pounder to drive a 7-ft section of 1-in.-diameter steel pipe with a removable steel drive point. After the pipe was driven to a depth of approximately $3 \mathrm{ft}$ below the lakebed, a section of 3/8-in.-diameter polyethylene tubing attached to a 6in-long stainless steel wire mesh screen was inserted into the tubing. The 1-in.-diameter steel pipe was subsequently removed, and the piezometer was developed by pumping water from the piezometer using a peristaltic pump for about 30-60 minutes until the piezometer produced clear water.

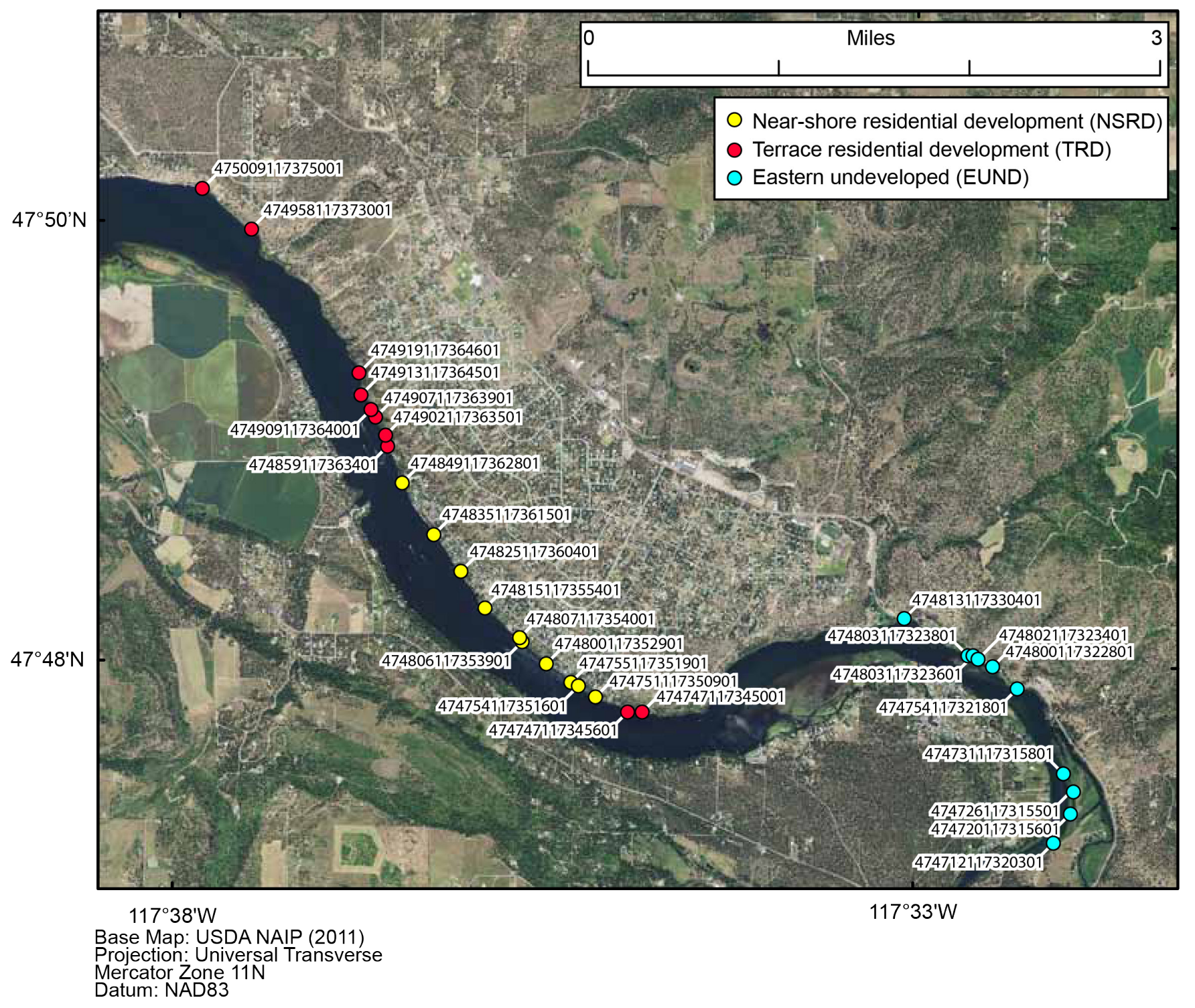

Figure 3. Map showing location of shallow piezometers installed at 30 locations near the shoreline of Lake Spokane, northeastern Washington. 
Preparation of sampling equipment and collection of groundwater samples for water-quality analysis followed standard USGS practices (U.S. Geological Survey, variously dated; Wagner and others, 2007; Kozar and Kahle, 2013). Sample collection bottles were rinsed with de-ionized water followed by filtered native water before each sample was collected. Before sampling, $0.45-\mu \mathrm{m}$ capsule filters were conditioned by purging them with $1 \mathrm{~L}$ of de-ionized water. The collection and processing of water samples followed standard USGS practices as described in Wilde (2004) and Wilde and others (2004). Samples were immediately placed over ice after they were collected and kept chilled during shipment to the USGS National Water Quality Laboratory.

The non-parametric Wilcoxon rank-sum test was used to assess whether nutrient concentrations measured in groundwater collected downgradient of each of the land uses are significantly different (Helsel and Hirsch, 2002). The null hypothesis that no difference between the populations of nutrient concentrations collected downgradient of different land uses was rejected if the corresponding Wilcoxon rank-sum test yielded a $p$-value of $\leq 0.05$.

Quality-control samples including field blank water and sequentially collected field replicate samples were collected during the April and March sampling events. Field blanks were collected to identify the presence and magnitude of possible contamination that could originate from handling of equipment and supplies, preparation, collection, and handling of samples, or other factors such as environmental conditions, reagents, or instrumentation. Two field blank-water samples were prepared from reagent-grade reverse-osmosis water from the USGS Washington Water Science Center Laboratory that was passed through all collection and processing equipment onsite and into sample bottles submitted to the laboratory. In both field-water blanks, nitrate plus nitrite, orthophosphate, and total phosphorus concentrations were less than the reporting limits of $0.04,0.004$, and $0.10 \mathrm{mg} / \mathrm{L}$, respectively. An ammonia concentration for one field-water blank (474731117315801) was $0.10 \mathrm{mg} / \mathrm{L}$, while the other field-water blank was less than the $0.10 \mathrm{mg} / \mathrm{L}$ reporting limit.

Precision of analytical results are affected by many sources of variability within the field and laboratory environments including sample collection, processing, and analysis. To assess this variability, two field replicates were sequentially collected by filling two collection bottles one after the other at sites 474751117350901 on March 23, 2015, and 474800117352901 on March 26, 2015. Relative percent difference in the pairs of concentrations ranged from 0 percent for ammonia (both samples were less than the $0.10 \mathrm{mg} / \mathrm{L}$ reporting limit), 0.7-13.4 percent for nitrate plus nitrite, $2.4-3.7$ percent for orthophosphate, and 0 percent for total phosphorus.

Groundwater discharge was confirmed at most sites by measuring the difference in hydraulic head between the lake and the underlying groundwater at 21 of the 30 piezometer locations using a manometer board that allows comparison of the hydraulic head of groundwater measured at the midpoint of the screen (Simonds and others, 2004). Vertical hydraulic gradients were computed by dividing the difference between the water levels in the surface water and the underlying groundwater by the depth of the midpoint of the screened interval beneath the streambed (Winter and others, 1988). Groundwater discharge is indicated when the water level inside the piezometer is higher than the water level of surface water. This condition indicates that the groundwater is moving into the surface water and, by convention, the vertical hydraulic gradient is assigned a positive value. Conversely, a lower water level in the piezometer relative to surface water is assigned a negative value and indicates that surface water is moving into groundwater. 


\section{Results}

\section{$\delta^{15} \mathrm{~N}$ of Aquatic Vegetation}

Relative abundances of $\delta^{15} \mathrm{~N}$ were measured from Richardson's pondweed collected at 84 sites in the near-shore area of Lake Spokane downgradient of four land uses - near-shore residential development (NSRD), terrace residential development (TRD), undeveloped land in eastern Lake Spokane (EUND), and undeveloped land in central Lake Spokane (CUND). $\delta^{15} \mathrm{~N}$ values of Richardson's pondweed samples are summarized in table 1 and figure 4 and detailed in table A1. The $\delta^{15} \mathrm{~N}$ values were not significantly different between Richardson's pondweed sample collected from NSRD and TRD land uses (Wilcoxon rank sum test; $p$-value 0.29 ). The $\delta^{15} \mathrm{~N}$ value of Richardson's pondweed collected downgradient of EUND was significantly less than that of Richardson's pondweed collected downgradient of NSRD (Wilcoxon rank sum test; $p$-value 0.004), TRD (Wilcoxon rank sum test; $p$ value $<0.001$ ), and CUND (Wilcoxon rank sum test; $p$-value $<0.001$ ). Conversely, the $\delta^{15} \mathrm{~N}$ value of Richardson's pondweed collected downgradient of CUND is significantly greater than that of the $\delta^{15} \mathrm{~N}$ value of Richardson's pondweed collected downgradient of NSRD (Wilcoxon rank sum test; $p$-value 0.003 ), TRD (Wilcoxon rank sum test; $p$-value 0.010), and EUND (Wilcoxon rank sum test; $p$-value $<0.001)$.

Table 1. Summary statistics of $\delta^{15} \mathrm{~N}$ values in Richardson's pondweed for sampled land uses in Lake Spokane, northeastern Washington.

\begin{tabular}{lccc}
\hline \multicolumn{1}{c}{ Upgradient land use } & Number of & \multicolumn{2}{c}{$\boldsymbol{\delta}^{15 \mathrm{~N}}(\% \mathrm{\%})$} \\
\cline { 3 - 4 } & samples & Median & Interquartile range \\
\hline Near-shore residential development (NSRD) & 21 & 7.41 & 1.80 \\
Terrace residential development (TRD) & 31 & 7.77 & 1.41 \\
Undeveloped land in eastern Lake Spokane (EUND) & 12 & 6.07 & 1.64 \\
Undeveloped land in central Lake Spokane (CUND) & 20 & 8.59 & 0.78 \\
\hline
\end{tabular}



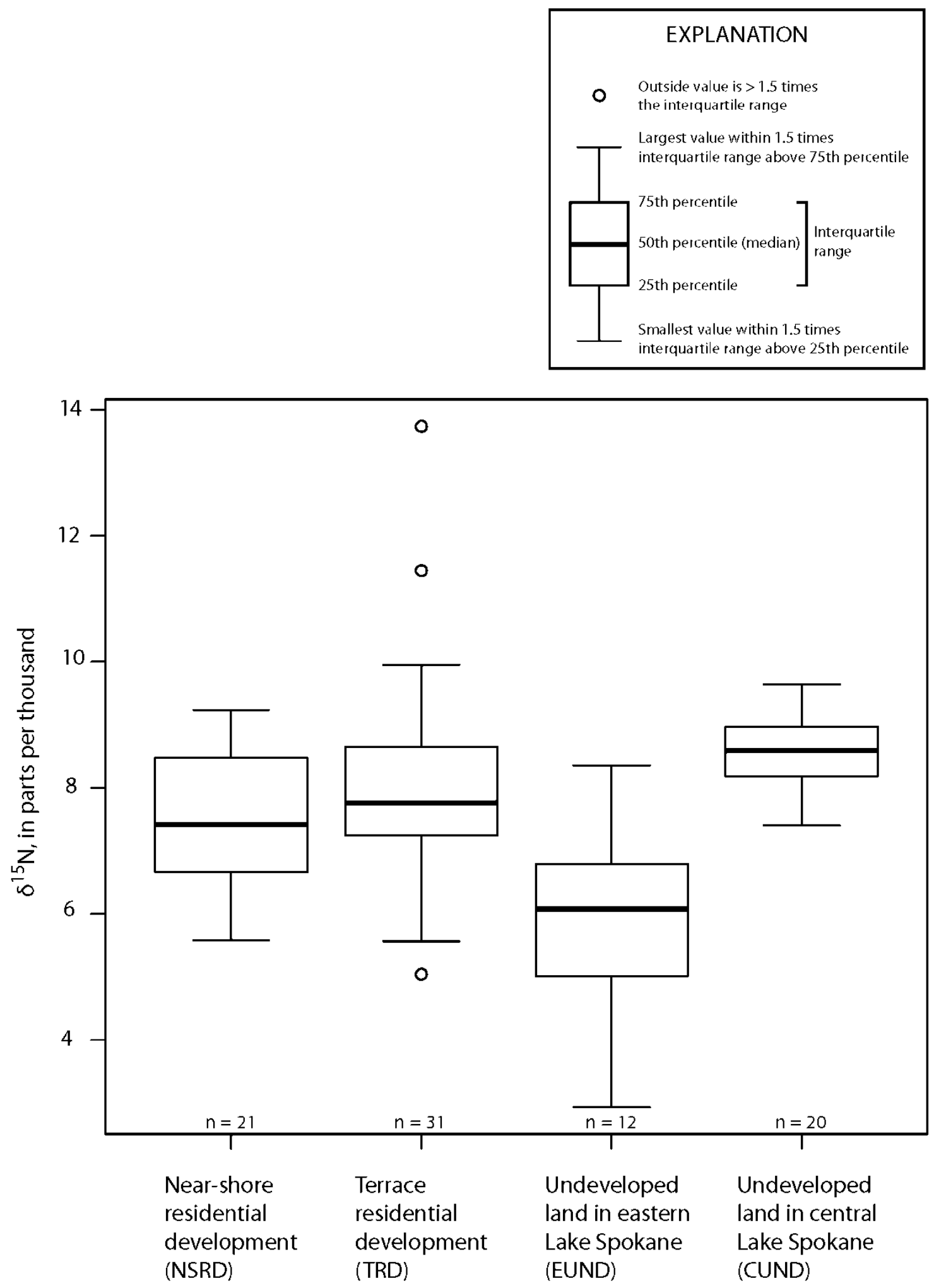

Figure 4. Boxplot showing $\delta^{15} \mathrm{~N}$ in Richardson's pondweed for sampled land uses in Lake Spokane, northeastern Washington. 


\section{Nitrogen and Phosphorus Concentrations in Shallow Groundwater}

Nutrient concentrations in groundwater collected at 30 shallow piezometers near the shoreline of Lake Spokane during March and April 2015 are summarized in table 2 and detailed in table A2. Ten piezometers were located downgradient of each of the three types of land uses-NSRD, TRD, and EUND. Hydraulic gradient between groundwater and surface water was measured at 21 of the 30 shallow piezometers. A positive hydraulic gradient was measured at 17 piezometers, a negative hydraulic gradient was measured at 3 piezometers, and a neutral hydraulic gradient was measured at 1 piezometer (table A2). Most nitrogen concentrations measured in samples from the 30 piezometers were nitrate or nitrite, whereas ammonia concentrations of less than the $0.10 \mathrm{mg} / \mathrm{L}$ reporting limit were measured at 23 of the 30 piezometers. Median nitrate plus nitrite concentrations were $1.49 \mathrm{mg} / \mathrm{L}$ (interquartile range of $2.32 \mathrm{mg} / \mathrm{L}$ ) and ranged from less than the $0.04 \mathrm{mg} / \mathrm{L}$ reporting limit to a maximum of $4.92 \mathrm{mg} / \mathrm{L}$. Most phosphorus concentrations measured in samples from the 30 piezometers were orthophosphate, which ranged from 0.008 to $0.24 \mathrm{mg} / \mathrm{L}$, with a median concentration of 0.044 $\mathrm{mg} / \mathrm{L}$ (interquartile range of $0.047 \mathrm{mg} / \mathrm{L}$ ).

Table 2. Nitrogen and orthophosphate concentrations in groundwater for sampled land uses near the shoreline of Lake Spokane, northeastern Washington.

[mg/L, milligram per liter]

\begin{tabular}{|c|c|c|c|c|c|}
\hline \multirow[b]{2}{*}{ Upgradient land use } & \multirow{2}{*}{$\begin{array}{l}\text { Number of } \\
\text { samples }\end{array}$} & \multicolumn{2}{|c|}{ Nitrate plus nitrite (mg/L) } & \multicolumn{2}{|c|}{ Orthophosphate (mg/L) } \\
\hline & & Median & $\begin{array}{l}\text { Interquartile } \\
\text { range }\end{array}$ & Median & $\begin{array}{l}\text { Interquartile } \\
\text { range }\end{array}$ \\
\hline Near-shore residential development (NSRD) & 10 & 2.39 & 1.01 & 0.044 & 0.019 \\
\hline Terrace residential development (TRD) & 10 & 2.13 & 3.05 & 0.044 & 0.025 \\
\hline Undeveloped land in eastern Lake Spokane (EUND) & 10 & 0.58 & 0.88 & 0.043 & 0.088 \\
\hline
\end{tabular}

The relation between nutrient concentrations and upgradient land use varied. Nitrate plus nitrite concentrations downgradient of the EUND land use (median: $0.58 \mathrm{mg} / \mathrm{L}$; fig. 5) were significantly less than concentrations downgradient of NSRD land use (median: $2.39 \mathrm{mg} / \mathrm{L}$; Wilcoxon rank sum test, $p$ value $<0.001)$. Nitrate plus nitrite concentrations downgradient of the EUND and TRD land uses (median: $2.13 \mathrm{mg} / \mathrm{L}$; Wilcoxon rank sum test, $p$-value 0.14 ) were not significantly different. Orthophosphate concentrations at piezometers downgradient of EUND (median: $0.043 \mathrm{mg} / \mathrm{L}$; fig. 6) and either NSRD (median: $0.044 \mathrm{mg} / \mathrm{L}$; Wilcoxon rank sum test, $p$-value 1) or TRD (median: $0.044 \mathrm{mg} / \mathrm{L}$; Wilcoxon rank sum test, $p$-value 0.910 ) were not significantly different. 

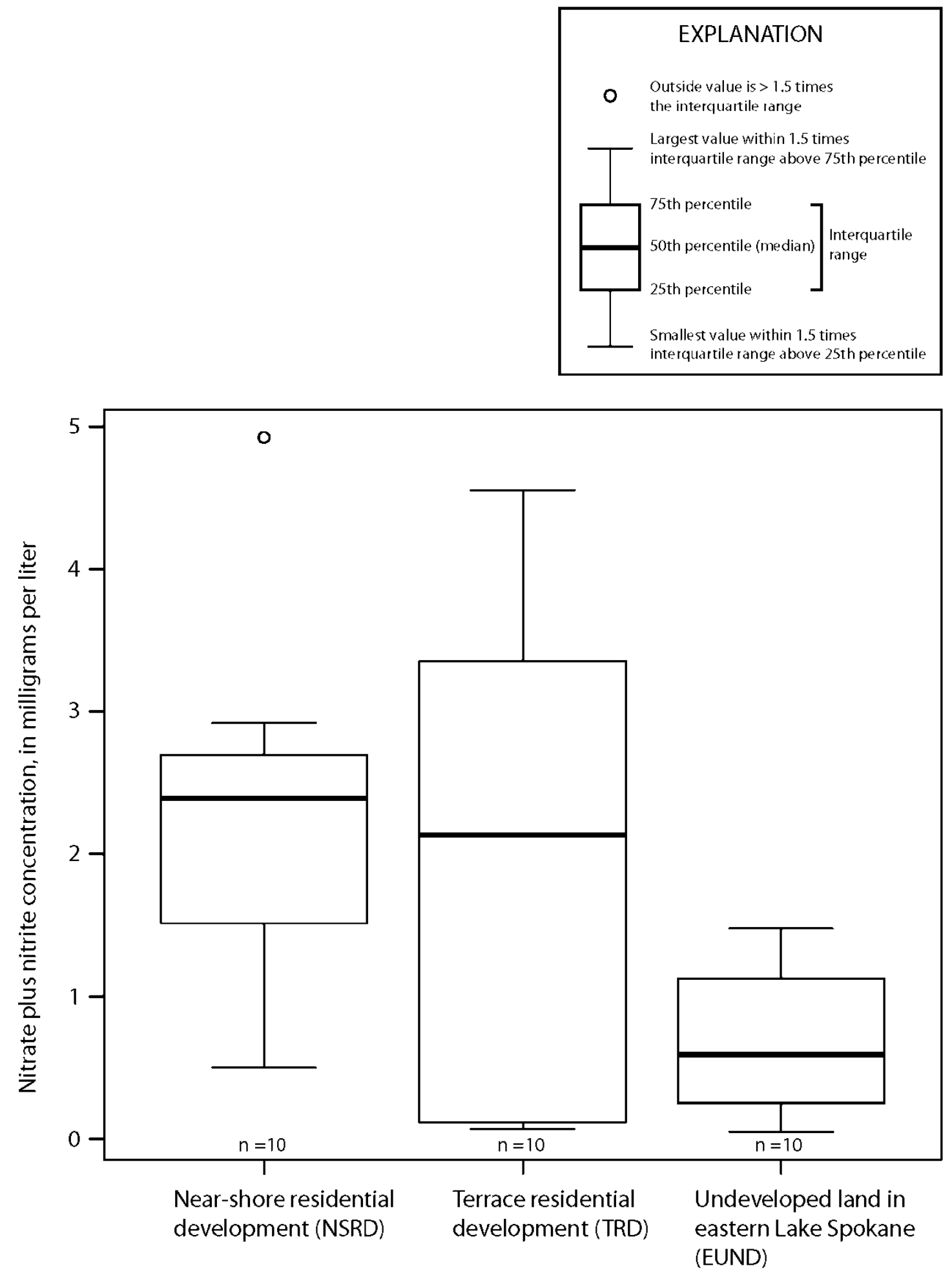

Figure 5. Boxplot showing nitrate plus nitrite concentrations in groundwater for sampled land uses near the shoreline of Lake Spokane, northeastern Washington. 


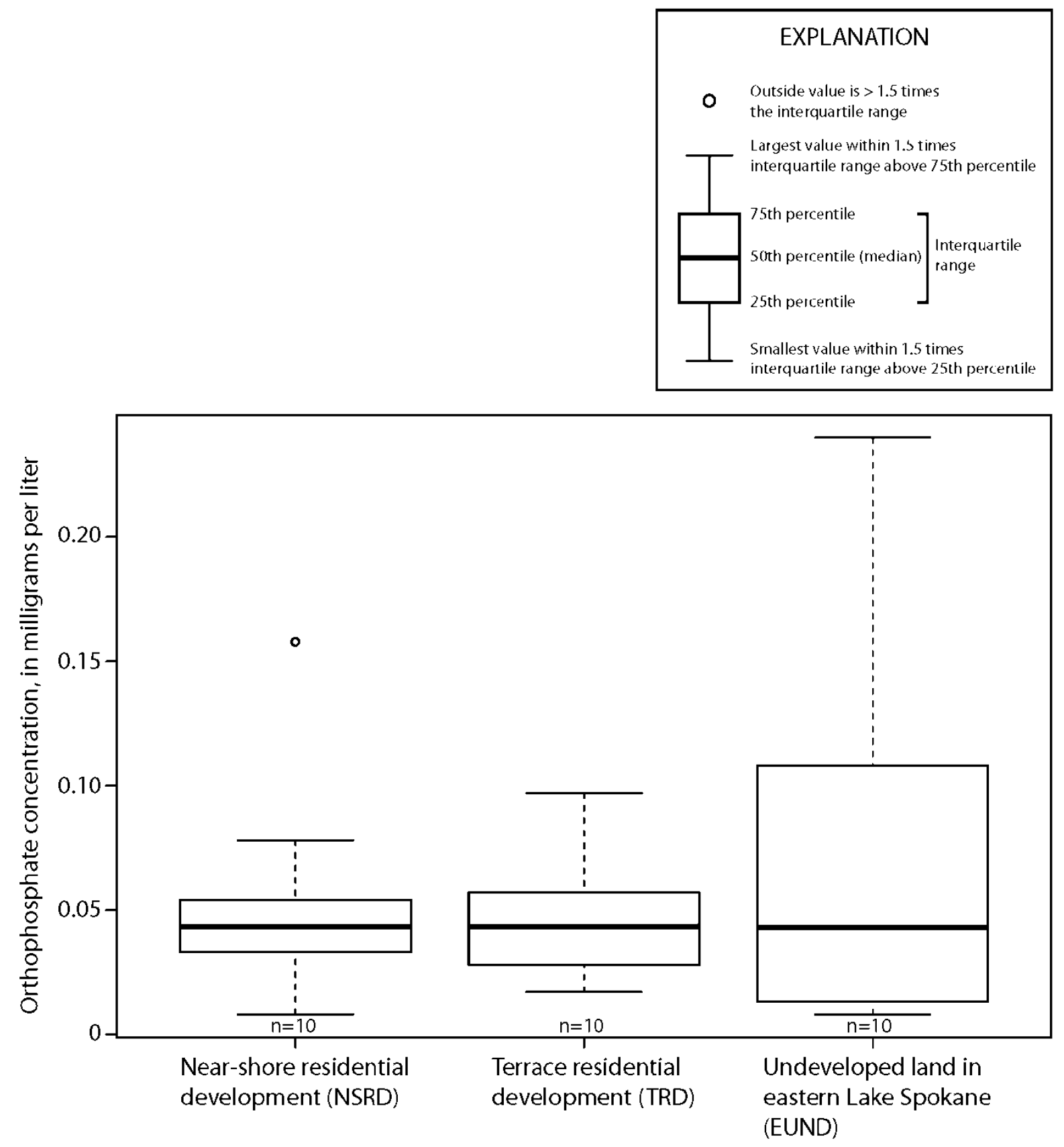

Figure 6. Boxplot showing orthophosphate concentrations in groundwater for sampled land uses near the shoreline of Lake Spokane, northeastern Washington. 


\section{Discussion}

The indication of septic wastewater in Lake Spokane downgradient of different land uses was analyzed by measuring the $\delta^{15} \mathrm{~N}$ value of Richardson's pondweed in August and September 2014. These data were used to guide the location of subsequent groundwater sampling in March and April 2015. The $\delta^{15} \mathrm{~N}$ value of Richardson's pondweed, which is integrated across the spring and summer growing season, was enriched in $\delta^{15} \mathrm{~N}$ (that is, isotopically heavier) in samples downgradient of all four land uses relative to the atmosphere (table 1). There was no statistical difference between $\delta^{15} \mathrm{~N}$ values of pondweed samples collected downgradient of the NSRD and TRD land uses. However, the $\delta^{15} \mathrm{~N}$ value of pondweed sampled downgradient of the NSRD and TRD land uses was significantly higher than pondweed sampled downgradient of EUND, but was significantly lower than pondweed sampled downgradient of CUND. Independent measurements of groundwater flux were not made during the growing season when the pondweed integrated its $\delta^{15} \mathrm{~N}$ value; thus, the $\delta^{15} \mathrm{~N}$ value of plants may reflect the $\delta^{15} \mathrm{~N}$ value of surface water where groundwater is not discharging to the lake. In part, uptake of surface water by plants via pore water roots may explain the discrepancy between the $\delta^{15} \mathrm{~N}$ values of pondweed sampled downgradient of EUND and CUND land uses. In the absence of independent groundwater-discharge data, subsequent groundwater sampling of nutrients was focused downgradient of EUND land use, which had a relatively lower $\delta^{15} \mathrm{~N}$ value (that is, isotopically lighter), for comparison to groundwater sampled downgradient of NSRD and TRD land uses.

Nutrient concentrations, including phosphorus and nitrogen, were measured at 30 piezometers in March and April 2015 downgradient of the EUND land use for comparison to groundwater sampled downgradient of NSRD and TRD land uses. No significant difference was measured in orthophosphate concentrations between sample locations downgradient of the EUND area and the two developed land uses (NSRD and TRD). Conversely, nitrate plus nitrite in groundwater sampled downgradient of the EUND land use was significantly less than nitrate plus nitrite in groundwater sampled downgradient of the two developed land uses (NSRD and TRD). Nitrogen, primarily in the form of nitrate, does not react with sediments or other aquifer materials and thus moves readily through groundwater, but may be attenuated by denitrifying microbes, which are present in most surficial aquifers (Chapelle, 1993). Relative to nitrogen, phosphorus is relatively immobile in groundwater because it sorbs onto soils and aquifer materials (U.S. Geological Survey, 1999). The concentration of iron oxides and clay minerals within aquifer materials as well as geochemical conditions within the aquifer, such as low $\mathrm{pH}$, increase an aquifer's sorption of phosphorus and limit the ability of phosphorus to discharge into surface-water bodies (Domagalski and Johnson, 2011). Continued loading of phosphorus saturates the sorption sites, leading to breakthrough and movement of additional phosphorus supplied to the aquifer. The lack of statistical difference between phosphorus concentrations measured downgradient of sampled areas with high densities of OSS (for example, NSRD and TRD land uses) and low densities of OSS (EUND land use) suggests that breakthrough conditions with respect to phosphorus do not exist in the area sampled. However, positive vertical hydraulic gradients suggest that groundwater does result in some nutrient inputs to the lake. 


\section{Summary and Conclusions}

Nitrogen-isotope analyses of Richardson's pondweed sampled downgradient of land uses with varying degrees of development and on-site septic system densities suggest that septic system influence was less for the undeveloped land in eastern Lake Spokane (EUND) than either developed land (NSRD and TRD) or undeveloped land in central Lake Spokane (CUND). Nitrogen concentrations in groundwater, as measured by nitrate plus nitrite, downgradient of the undeveloped land in eastern Lake Spokane (EUND) was significantly less than both of the developed land uses (NSRD and TRD).

Orthophophate concentrations in groundwater, however, which is less mobile in groundwater because it sorbs readily to sediments, was not significantly different between samples collected downgradient of the undeveloped land in eastern Lake Spokane (EUND) and either of the developed land uses (NSRD and TRD). These data indicate that aquifer materials downgradient of on-site septic systems have not been saturated with respect to phosphorus and breakthrough conditions do not exist. Because phosphorus and nitrogen concentrations in groundwater were only measured in March and April 2015, temporal variability of these concentrations remains unknown.

\section{Acknowledgments}

The authors would like to thank private landowners and citizens of the area surrounding Lake Spokane for access to sites along the shoreline of Lake Spokane. The authors would also like to thank members of the Lake Spokane Association, Llyn Doremus, Ted Hamlin, and Wyatt Plastino for field assistance.

\section{References Cited}

Chapelle, F.H., 1993, Ground-water microbiology \& geochemistry: New York, John Wiley \& Sons, Inc., 424 p.

Cole, M.L., Kroeger, K.D., McClelland, J.W., and Valiela, I., 2005, Macrophytes as indicators of landderived wastewater-Application of a $\delta^{15} \mathrm{~N}$ method in aquatic systems: Water Resources Research, $\mathrm{v}$. 41, W01014. [Also available at http://dx.doi.org/10.1029/2004WR003269.]

Cusimano, B., 2004, Spokane River and Lake Spokane (Long Lake) pollutant loading assessment for protecting dissolved oxygen: Washington State Department of Ecology Publication 04-03-006, $102 \mathrm{p}$.

Domagalski, J.L., and Johnson, H.M., 2011, Subsurface transport of orthophosphate in five agricultural watersheds, USA: Journal of Hydrology, v. 409, p.157-171. [Also available at http://dx.doi.org/10.1016/j.jhydrol.2011.08.014.]

Finlay, J.C., and Kendall, C., 2007, Stable isotope tracing of temporal and spatial variability in organic matter sources to freshwater ecosystems, in Michener, R.H., and Lajtha, K., eds., Stable isotopes in ecology and environmental science (2d ed.): Oxford, Blackwell Publishing, chap. 10, p. 283-333.

Helsel, D.R., and Hirsch, R.M., 2002, Statistical methods in water resources: U.S. Geological Survey Techniques of Water-Resources Investigations, book 4, chap. A3, 522 p. [Also available at http://pubs.usgs.gov/twri/twri4a3/.]

Kendall, C., 1998, Tracing nitrogen sources and cycling in catchments, in Kendall, C., and McDonnell, J.J., eds., Isotope tracers in catchment hydrology: Amsterdam, Elsevier, p. 519-576.

Kendall, C., Elliott, E.M., and Wankel, S.D., 2007, Tracing anthropogenic inputs of nitrogen to ecosystems, in Michener, R.H., and Lajtha, K., eds., Stable isotopes in ecology and environmental science (2d ed.): Oxford, Blackwell Publishing, p. 375-449. 
Kozar, M.D., and Kahle, S.C., 2013, Quality-assurance plan for groundwater activities, U.S. Geological Survey, Washington Water Science Center: U.S. Geological Survey Open-File Report 2013-1151, 88 p. [Also available at http://pubs.usgs.gov/ofr/2013/1151/.]

Moore, D.J., and Ross, J., 2010, Spokane River and Lake Spokane dissolved oxygen total maximum daily load-Water quality improvement report: Washington State Department of Ecology Publication 07-10-073, $92 \mathrm{p}$.

Patmont, C.R., Pelletier, G.J., Singleton, L., Soltero, R., Trial, W., and Welch, E., 1987, The Spokane River Basin-Allowable phosphorus loading: Washington State Department of Ecology Publication No. 87-e29, 186 p.

Peterson, B.J., and Fry, B., 1987, Stable isotopes in ecosystem studies: Annual Review of Ecology and Systematics, v. 18, p. 293-320.

Simonds, F.W., Longpré, C.I., and Justin, G.B., 2004, Groundwater system in the Chimacum Creek Basin and surface water/ground water interaction in Chimacum and Tarboo Creeks and the Big and Little Quilcene Rivers, Eastern Jefferson County, Washington: U.S. Geological Survey Scientific Investigations Report 2004-5058, 49 p. [Also available at http://pubs.usgs.gov/sir/2004/5058/.]

Soltero, R.A., Sexton, L.M., Wargo, L.L., Geiger, D.D., Roberton, K.S., Bolstad, K.E., Buchanan, J.P., and Johnson, M.S.,1992, Assessment of nutrient loading sources and macrophyte growth in Long Lake (Lake Spokane), WA and the feasibility of various control measures: Cheney, Eastern Washington University, Departments of Biology and Geology.

U.S. Census Bureau, 2015, Population, GIS data, Census 2000 and 2010 Tiger/Line files: U.S. Census Bureau database, accessed November 1, 2015, at https:/www.census.gov/geo/maps-data/data/tigerdata.html.

U.S. Geological Survey, variously dated, National field manual for the collection of water-quality data: U.S. Geological Survey Techniques of Water-Resources Investigations, book 9, chaps. A1-A10, accessed April 5, 2013, at http://water.usgs.gov/owq/FieldManual/.

U.S. Geological Survey, 1999, The quality of our nation's waters-Nutrients and pesticides: U.S. Geological Survey Circular 1225, 82 p.

Wagner, R.J., Kimbrough, R.A., and Turney, G.L., 2007, Quality-assurance plan for water-quality activities in the U.S. Geological Survey Washington Water Science Center: U.S. Geological Survey Open-File Report 2007-1307, 49 p.

Wagstaff, W.H., and Soltero, R.A., 1982, The cause(s) of continued hypolimnetic anoxia in Lake Spokane, Washington following advanced wastewater treatment by the City of Spokane: Cheney, Eastern Washington University, Department of Biology.

Wilde, F.D., ed., 2004, Cleaning of equipment for water sampling (ver. 2.0): U.S. Geological Survey Techniques of Water-Resources Investigations, book 9, chap. A3.

Wilde, F.D., Radtke, D.B., Gibs, Jacob, and Iwatsubo, R.T., eds., 2004 with updates through 2009, Processing of water samples (ver. 2.2): U.S. Geological Survey Techniques of Water-Resources Investigations, book 9, chap. A5, April 2004, accessed November 1, 2015, at http://pubs.water.usgs.gov/twri9A5/.

Winter, T.C., Harvey, J.W., Franke, O.L., and Alley, W.M., 1998, Ground water and surface water a single resource: U.S. Geological Survey Circular 1139, 79 p. 
This page left intentionally blank 


\section{Appendix A.}

Table A1. $\delta^{15} \mathrm{~N}$ values measured in Richardson's pondweed in Lake Spokane, northeastern Washington.

[Upgradient land use: CUND, undeveloped land in central Lake Spokane; EUND, undeveloped land in eastern Lake Spokane; NSRD, near-shore residential development; TRD, terrace residential development]

\begin{tabular}{|c|c|c|c|c|}
\hline $\begin{array}{l}\text { U.S. Geological } \\
\text { Survey } \\
\text { site No. }\end{array}$ & Upgradient land use & Date & Time & $\delta^{15} \mathrm{~N}(\%)$ \\
\hline 474834117361401 & NSRD & $8 / 19 / 2014$ & 1207 & 6.67 \\
\hline 474835117361601 & NSRD & $8 / 19 / 2014$ & 1145 & 6.53 \\
\hline 474838117361801 & NSRD & $8 / 19 / 2014$ & 1122 & 8.23 \\
\hline 474843117362401 & NSRD & $8 / 19 / 2014$ & 1231 & 8.17 \\
\hline 474847117362701 & NSRD & $8 / 19 / 2014$ & 1254 & 8.76 \\
\hline 474853117363001 & TRD & $8 / 19 / 2014$ & 1310 & 6.84 \\
\hline 474859117363501 & TRD & $8 / 19 / 2014$ & 1328 & 8.03 \\
\hline 474826117360601 & NSRD & $8 / 19 / 2014$ & 1429 & 7.41 \\
\hline 474823117360301 & NSRD & $8 / 19 / 2014$ & 1450 & 8.96 \\
\hline 474821117360001 & NSRD & $8 / 19 / 2014$ & 1502 & 7.19 \\
\hline 474819117355701 & NSRD & $8 / 19 / 2014$ & 1515 & 6.67 \\
\hline 474814117355201 & NSRD & $8 / 19 / 2014$ & 1528 & 6.91 \\
\hline 475012117381701 & TRD & $8 / 20 / 2014$ & 0947 & 6.54 \\
\hline 475009117375201 & TRD & $8 / 20 / 2014$ & 1012 & 5.04 \\
\hline 475009117374901 & TRD & $8 / 20 / 2014$ & 1023 & 7.30 \\
\hline 475008117374801 & TRD & $8 / 20 / 2014$ & 1038 & 7.17 \\
\hline 475007117374501 & TRD & $8 / 20 / 2014$ & 1051 & 7.38 \\
\hline 475006117374401 & TRD & $8 / 20 / 2014$ & 1102 & 8.85 \\
\hline 475005117374301 & TRD & $8 / 20 / 2014$ & 1118 & 7.42 \\
\hline 475003117373901 & TRD & $8 / 20 / 2014$ & 1130 & 8.36 \\
\hline 475002117373801 & TRD & $8 / 20 / 2014$ & 1136 & 7.69 \\
\hline 474959117373401 & TRD4 & $8 / 20 / 2014$ & 1153 & 7.84 \\
\hline 474957117373001 & TRD & $8 / 20 / 2014$ & 1207 & 9.00 \\
\hline 474957117372801 & TRD & $8 / 20 / 2014$ & 1215 & 7.12 \\
\hline 474955117372601 & TRD & $8 / 20 / 2014$ & 1302 & 7.72 \\
\hline 474954117372701 & TRD & $8 / 20 / 2014$ & 1315 & 7.72 \\
\hline 475010117375601 & TRD & $8 / 20 / 2014$ & 1331 & 5.80 \\
\hline
\end{tabular}




\begin{tabular}{|c|c|c|c|c|}
\hline $\begin{array}{l}\text { U.S. Geological } \\
\text { Survey } \\
\text { site No. }\end{array}$ & Upgradient land use & Date & Time & $\delta^{15} \mathrm{~N}(\%)$ \\
\hline 475010117375801 & TRD & $8 / 20 / 2014$ & 1342 & 7.98 \\
\hline 475010117380001 & TRD & $8 / 20 / 2014$ & 1347 & 5.57 \\
\hline 475010117380301 & TRD & $8 / 20 / 2014$ & 1356 & 8.02 \\
\hline 475010117380601 & TRD & $8 / 20 / 2014$ & 1411 & 7.50 \\
\hline 474810117354601 & NSRD & $8 / 20 / 2014$ & 1534 & 9.24 \\
\hline 474807117354101 & NSRD & $8 / 20 / 2014$ & 1552 & 8.74 \\
\hline 474806117354001 & NSRD & $8 / 20 / 2014$ & 1607 & 8.47 \\
\hline 475235117420501 & CUND & $8 / 21 / 2014$ & 0941 & 8.00 \\
\hline 475235117420401 & CUND & $8 / 21 / 2014$ & 0951 & 8.43 \\
\hline 475240117420201 & CUND & $8 / 21 / 2014$ & 1007 & 7.40 \\
\hline 475241117420101 & CUND & $8 / 21 / 2014$ & 1016 & 9.64 \\
\hline 475242117420001 & CUND & $8 / 21 / 2014$ & 1024 & 8.30 \\
\hline 475244117415801 & CUND & $8 / 21 / 2014$ & 1043 & 8.49 \\
\hline 475245117415701 & CUND & $8 / 21 / 2014$ & 1050 & 8.68 \\
\hline 475244117415701 & CUND & $8 / 21 / 2014$ & 1057 & 7.96 \\
\hline 475246117415701 & CUND & $8 / 21 / 2014$ & 1105 & 9.48 \\
\hline 475247117415801 & CUND & $8 / 21 / 2014$ & 1114 & 8.16 \\
\hline 475248117415701 & CUND & $8 / 21 / 2014$ & 1128 & 8.20 \\
\hline 475243117413301 & CUND & $8 / 21 / 2014$ & 1145 & 8.82 \\
\hline 475240117413601 & CUND & $8 / 21 / 2014$ & 1156 & 8.43 \\
\hline 475242117413401 & CUND & $8 / 21 / 2014$ & 1235 & 8.75 \\
\hline 475243117413101 & CUND & $8 / 21 / 2014$ & 1245 & 8.97 \\
\hline 475244117413101 & CUND & $8 / 21 / 2014$ & 1252 & 9.09 \\
\hline 475245117413001 & CUND & $8 / 21 / 2014$ & 1259 & 8.98 \\
\hline 475246117412901 & CUND & $8 / 21 / 2014$ & 1307 & 7.77 \\
\hline 475243117413201 & CUND & $8 / 21 / 2014$ & 1316 & 8.73 \\
\hline 475242117413301 & CUND & $8 / 21 / 2014$ & 1324 & 9.17 \\
\hline 474805117353701 & NSRD & $8 / 21 / 2014$ & 1538 & 6.69 \\
\hline 474804117353501 & NSRD & $8 / 21 / 2014$ & 1548 & 7.64 \\
\hline 474803117353301 & NSRD & $8 / 21 / 2014$ & 1604 & 7.98 \\
\hline 474905117363701 & TRD & $9 / 16 / 2014$ & 1011 & 8.00 \\
\hline 474904117363701 & TRD & $9 / 16 / 2014$ & 1014 & 7.77 \\
\hline
\end{tabular}




\begin{tabular}{|c|c|c|c|c|}
\hline $\begin{array}{l}\text { U.S. Geological } \\
\text { Survey } \\
\text { site No. }\end{array}$ & Upgradient land use & Date & Time & $\delta^{15} \mathrm{~N}(\%)$ \\
\hline 474906117363901 & TRD & $9 / 16 / 2014$ & 1025 & 8.95 \\
\hline 474909117363901 & TRD & $9 / 16 / 2014$ & 1031 & 8.45 \\
\hline 474803117340901 & TRD & $9 / 16 / 2014$ & 1127 & 6.94 \\
\hline 474913117364401 & TRD & $9 / 16 / 2014$ & 1203 & 13.73 \\
\hline 474914117364501 & TRD & $9 / 16 / 2014$ & 1216 & 11.44 \\
\hline 474917117364501 & TRD & $9 / 16 / 2014$ & 1246 & 9.86 \\
\hline 474918117364601 & TRD & $9 / 16 / 2014$ & 1257 & 9.95 \\
\hline 474919117364701 & TRD & $9 / 16 / 2014$ & 1306 & 8.95 \\
\hline 474749117350301 & NSRD & $9 / 16 / 2014$ & 1305 & 5.68 \\
\hline 474750117350501 & NSRD & $9 / 16 / 2014$ & 1350 & 5.58 \\
\hline 474751117350701 & NSRD & $9 / 16 / 2014$ & 1414 & 9.00 \\
\hline 474753117351301 & NSRD & $9 / 16 / 2014$ & 1436 & 6.54 \\
\hline 474801117352901 & NSRD & $9 / 17 / 2014$ & 1020 & 6.21 \\
\hline 474755117322001 & EUND & $9 / 17 / 2014$ & 1117 & 4.46 \\
\hline 474754117321701 & EUND & $9 / 17 / 2014$ & 1140 & 4.87 \\
\hline 474721117325501 & EUND & $9 / 17 / 2014$ & 1248 & 6.93 \\
\hline 474725117315501 & EUND & $9 / 17 / 2014$ & 1304 & 6.31 \\
\hline 474732117315901 & EUND & $9 / 17 / 2014$ & 1408 & 6.65 \\
\hline 474732117315801 & EUND & $9 / 17 / 2014$ & 1418 & 5.84 \\
\hline 474733117320001 & EUND & $9 / 17 / 2014$ & 1428 & 6.57 \\
\hline 474740117300501 & EUND & $9 / 17 / 2014$ & 1439 & 8.35 \\
\hline 474801117323101 & EUND & $9 / 17 / 2014$ & 1518 & 5.15 \\
\hline 474801117323301 & EUND & $9 / 17 / 2014$ & 1530 & 6.93 \\
\hline 474802117323501 & EUND & $9 / 17 / 2014$ & 1548 & 2.94 \\
\hline 474803117323701 & EUND & $9 / 17 / 2014$ & 1602 & 5.71 \\
\hline
\end{tabular}


Table A2. Water-quality data measured at shallow piezometers for land uses near the shoreline of Lake Spokane, northeastern Washington.

[Locations of shallow piezometers are shown in figure 3. Upgradient land use: CUND, undeveloped land in central Lake Spokane;

EUND, undeveloped land in eastern Lake Spokane; NSRD, near-shore residential development; TRD, terrace residential development;

BLNK, blank sample; REP, replicate sample. Hydraulic gradient: +, positive; -, negative; n.m., not measured. Additional data available in the U.S. Geological Survey National Water Information at http://nwis.waterdata.usgs.gov/nwis. N, nitrogen; P, phosphorus]

\begin{tabular}{|c|c|c|c|c|c|c|c|c|c|}
\hline USGS Site No. & $\begin{array}{l}\text { Upgradient } \\
\text { land use }\end{array}$ & Date & Time & $\begin{array}{c}\text { Specific } \\
\text { conductance }\end{array}$ & $\begin{array}{c}\text { Hydraulic } \\
\text { gradient }\end{array}$ & $\begin{array}{l}\text { Ammonia } \\
\text { (mg/L as } \mathrm{N})\end{array}$ & $\begin{array}{l}\text { Nitrate plus } \\
\text { nitrite } \\
\text { (mg/L as } \mathrm{N} \text { ) }\end{array}$ & $\begin{array}{c}\text { Ortho- } \\
\text { phosphate } \\
\text { (mg/L as P) }\end{array}$ & $\begin{array}{c}\text { Total } \\
\text { dissolved } \\
\text { phosphorus } \\
\text { (mg/L as P) }\end{array}$ \\
\hline 474755117351901 & NSRD & $3 / 24 / 2015$ & 1150 & 375 & + & 0.18 & 0.321 & 0.008 & 0.04 \\
\hline 474754117351601 & NSRD & $3 / 24 / 2015$ & 1220 & 554 & n.m. & $<0.01$ & 4.92 & 0.033 & 0.03 \\
\hline 474751117350901 & NSRD & $3 / 24 / 2015$ & 1400 & 427 & n.m. & $<0.01$ & 2.69 & 0.054 & 0.05 \\
\hline 474806117353901 & NSRD & $3 / 24 / 2015$ & 1540 & 406 & + & $<0.01$ & 2.69 & 0.078 & 0.07 \\
\hline 474807117354001 & NSRD & $3 / 24 / 2015$ & 1620 & 425 & + & 0.02 & 2.90 & 0.048 & 0.05 \\
\hline 474849117362801 & NSRD & $3 / 25 / 2015$ & 1000 & 619 & + & $<0.01$ & 2.21 & 0.158 & 0.16 \\
\hline 474815117355401 & NSRD & $3 / 25 / 2015$ & 1620 & 458 & + & $<0.01$ & 2.19 & 0.034 & 0.03 \\
\hline 474800117352901 & NSRD & $3 / 26 / 2015$ & 1650 & 360 & n.m. & $<0.01$ & 1.51 & 0.041 & 0.04 \\
\hline 474835117361501 & NSRD & $4 / 29 / 2015$ & 1350 & 560 & + & $<0.01$ & 2.56 & 0.046 & 0.04 \\
\hline 474825117360401 & NSRD & $4 / 29 / 2015$ & 1510 & 331 & + & $<0.01$ & 1.50 & 0.028 & 0.03 \\
\hline 474859117363401 & TRD & $3 / 25 / 2015$ & 1100 & 598 & + & $<0.01$ & 0.112 & 0.086 & 0.08 \\
\hline 474902117363501 & TRD & $3 / 25 / 2015$ & 1130 & 461 & + & $<0.01$ & 0.108 & 0.028 & 0.03 \\
\hline 474907117363901 & TRD & $3 / 25 / 2015$ & 1220 & 528 & n.m. & $<0.01$ & 2.78 & 0.027 & 0.02 \\
\hline 474913117364501 & TRD & $3 / 25 / 2015$ & 1240 & 539 & - & $<0.01$ & 4.55 & 0.042 & 0.04 \\
\hline 475009117375001 & TRD & $3 / 25 / 2015$ & 1400 & 488 & - & 0.05 & $<0.040$ & 0.017 & 0.02 \\
\hline 474958117373001 & TRD & $3 / 25 / 2015$ & 1440 & 156 & - & $<0.01$ & 0.287 & 0.045 & 0.05 \\
\hline 474747117345601 & TRD & $4 / 30 / 2015$ & 1140 & 601 & + & $<0.01$ & 3.35 & 0.097 & 0.10 \\
\hline 474747117345001 & TRD & $4 / 30 / 2015$ & 1010 & 386 & + & $<0.01$ & 2.10 & 0.034 & 0.03 \\
\hline 474909117364001 & TRD & $4 / 29 / 2015$ & 1230 & 571 & + & $<0.01$ & 2.16 & 0.057 & 0.05 \\
\hline 474919117364601 & TRD & $4 / 29 / 2015$ & 1320 & 547 & neutral & $<0.01$ & 4.51 & 0.048 & 0.03 \\
\hline 474803117323801 & EUND & $3 / 26 / 2015$ & 1150 & 484 & n.m. & $<0.01$ & 0.612 & 0.127 & 0.12 \\
\hline 474803117323601 & EUND & $3 / 26 / 2015$ & 1250 & 397 & n.m. & $<0.01$ & 0.406 & 0.083 & 0.07 \\
\hline 474802117323401 & EUND & $3 / 26 / 2015$ & 1330 & 706 & n.m. & 0.20 & 0.050 & 0.018 & 0.01 \\
\hline 474800117322801 & EUND & $3 / 26 / 2015$ & 1410 & 320 & n.m. & 0.01 & 0.556 & 0.061 & 0.07 \\
\hline 474813117330401 & EUND & $3 / 26 / 2015$ & 1540 & 484 & n.m. & $<0.01$ & 0.713 & 0.240 & 0.24 \\
\hline 474754117321801 & EUND & $4 / 30 / 2015$ & 1410 & 421 & + & 0.03 & $<0.040$ & 0.108 & 0.10 \\
\hline 474712117320301 & EUND & $4 / 30 / 2015$ & 1540 & 337 & + & 0.03 & $<0.040$ & 0.008 & $<0.01$ \\
\hline 474731117315801 & EUND & $4 / 30 / 2015$ & 1720 & 325 & + & $<0.01$ & 1.47 & 0.013 & $<0.01$ \\
\hline 474726117315501 & EUND & $4 / 30 / 2015$ & 1700 & 300 & + & $<0.01$ & 1.28 & 0.013 & $<0.01$ \\
\hline 474720117315601 & EUND & $4 / 30 / 2015$ & 1630 & 286 & + & $<0.01$ & 1.12 & 0.025 & 0.02 \\
\hline 474751117350901 & REP & $3 / 24 / 2015$ & 1401 & 427 & n.m. & $<0.01$ & 2.33 & 0.056 & 0.05 \\
\hline 474800117352901 & REP & $3 / 26 / 2015$ & 1651 & 360 & n.m. & $<0.01$ & 1.50 & 0.042 & 0.04 \\
\hline 474803117323801 & BLNK & $3 / 26 / 2015$ & 2300 & n.m. & n.m. & $<0.01$ & $<0.040$ & $<0.004$ & $<0.01$ \\
\hline 474731117315801 & BLNK & $5 / 1 / 2015$ & 2300 & 9.2 & n.m. & 0.01 & $<0.040$ & $<0.004$ & $<0.01$ \\
\hline
\end{tabular}


Publishing support provided by the U.S. Geological Survey

Science Publishing Network, Tacoma Publishing Service Center

For more information concerning the research in this report, contact the Director, Washington Water Science Center

U.S. Geological Survey

934 Broadway, Suite 300

Tacoma, Washington 98402

http://wa.water.usgs.gov 


\section{鄫}

을

言

울

1

ISSN 2331-1258 (online) 